\title{
Dampak Keberadaan Pariwisata Religi terhadap Perkembangan Ekonomi Masyarakat Cirebon
}

\author{
Ridwan Widagdo, Sri Rokhlinasari \\ Program Studi Perbankan Syariah, FSEI, IAIN Syekh Nurjati, Cirebon \\ Email: ridwanwidagdo@ymail.com
}

\begin{abstract}
Abstrak
Industri pariwisata mempunyai peranan penting dalam upaya pembangunan dan pengembangan suatu daerah. Bahkan pada beberapa daerah menunjukkan bahwa industri pariwisata mampu mendongkrak daerah tersebut dari keterbelakangan dan menjadikannya sebagai sumber pendapatan utama. Dampak dari adanya pariwisata yang menguntungkan seperti terciptanya lapangan pekerjaan, meningkatnya pendapatan, dan meningkatnya keramaian. Sedangkan dampak yang merugikan seperti mahalnya harga barang-barang, rusaknya daerah sekitar dan melunturnya kebudayaan.

Penelitian ini menggunakan pendekatan kualitatif di mana penulis berusaha mengekplorasi kedalaman data yang di peroleh dari wawancara dengan Responden sehingga data yang di peroleh menjadi valid untuk di analisis. Lokasi penelitian ini adalah tempat tempat wisata religi yang ada di Cirebon baik di kota maupun kabupaten. Data penelitian ini meliputi tiga data yaitu data primer, data sekunder, dan data tersier. Setelah data diperoleh, selanjutnya akan dianalisis dengan teknik analisis deskriptif-kualitatif.

Hasil yang diperoleh dari penelitian ini dapat disimpulkan bahwa adanya obyek wisata religi memiliki pengaruh yang sangat besar dalam pengembangan usaha untuk meningkatkan ekonomi masyarakat dan peningkatan ekonomi atau pengahasilan ini akan terasa cukup signifikan apabila ada moment-moment yang dilakukan oleh pihak pengelola pariwisata, dampak yang cukup signifikan lainya bagi kehidupan masyarakat Cirebon adalah dapat terciptanya lapangan pekerjaan baru untuk warga di sekitar tempat wisata baik untuk keluarga maupun untuk orang lain.
\end{abstract}

Kata kunci: Dampak, Pariwisata Religi, Ekonomi Masyarakat

\begin{abstract}
The tourism industry has an important role in development efforts and development of a region. Even in some areas indicate that the tourism industry is able to increase the area of backwardness and make it as a primary source of revenue. The effects of their lucrative tourism such as job creation, rising incomes, and increasing crowds. While the adverse impacts such as high prices of goods, damage to the surrounding area and lost of the culture.

This study uses a qualitative approach in which the author tried to explore the depth of the data that was obtained from interviews with respondents so that the data obtained into valid for in the analysis. The location of this research is a religious tourist spot in both the city and district of Cirebon. Data of the study contains of three kinds data, which are primary data, secondary data, and tertier data. Once the data is obtained, the next will be analyzed with descriptive qualitative analysis techniques.
\end{abstract}


The results of this study can be concluded that the object of religious tourism has enormous influence in the development effort to improve the local economy and increase in economics or income this can be quite significant if there are moments that made by the manager of tourism, a considerable impact significant other for a community in Cirebon is able to create new jobs for residents around the tourist attractions both for families and for others.

Key words: Impact, Religious Tourism, Economic Community

\section{Pendahuluan}

Pariwisata merupakan bagian dari sektor industri di Indonesia yang prospeknya cerah, dan mempunyai potensi serta peluang yang sangat besar untuk dikembangkan. Peluang tersebut didukung oleh kondisi-kondisi alamiah, seperti letak dan keadaan geografis (lautan dan daratan sekitar khatulistiwa), lapisan tanah yang subur dan panoramis (akibat ekologi geologis), serta berbagai flora dan fauna yang memperkaya isi daratan dan lautannya. ${ }^{1}$

Sektor pariwisata merupakan sektor yang potensial untuk dikembangkan sebagai salah satu sumber pendapatan daerah. Usaha memperbesar pendapatan asli daerah, maka program pengembangan dan pemanfaatan sumber daya dan potensi pariwisata daerah diharapkan dapat memberikan sumbangan bagi pembangunan ekonomi. Pariwisata dipandang sebagai kegiatan yang mempunyai multidimensi dari rangkaian proses pembangunan. Pembangunan sektor pariwisata menyangkut aspek sosial budaya, ekonomi dan politik. ${ }^{2}$

Hal tersebut sejalan dengan yang tercantum dalam Undang-Undang Nomor 10 tahun 2009 tentang Kepariwisataan yang menyatakan bahwa Penyelenggaraan Kepariwisataan ditujukan untuk

1 J James Spillane, Pariwisata Indonesia Siasat Ekonomi dan Rekayasa Kebudayaan. (Yogyakarta: Kanisius, 1994), hlm. 39

2 J James Spillane, Pariwisata Indonesia Siasat Ekonomi dan Rekayasa Kebudayaan. (Yogyakarta: Kanisius, 1994), hlm. 14 meningkatkan pendapatan nasional dalam rangka meningkatkan kesejahteraan dan kemakmuran rakyat, memperluas dan memeratakan kesempatan berusaha dan lapangan kerja, mendorong pembangunan daerah, memperkenalkan dan mendayagunakan obyek dan daya tarik wisata di Indonesia serta memupuk rasa cinta tanah air dan mempererat persahabatan antar bangsa. ${ }^{3}$

Perkembangan pariwisata juga mendorong dan mempercepat pertumbuhan ekonomi. Kegiatan pariwisata menciptakan permintaan, baik konsumsi maupun investasi yang pada gilirannya akan menimbulkan kegiatan produksi barang dan jasa. Selama berwisata, wisatawan berbelanja, sehingga secara langsung menimbulkan permintaan pasar barang dan jasa. Selanjutnya wisatawan secara tidak langsung menimbulkan permintaan akan barang modal dan bahan untuk berproduksi memenuhi permintaan wisatawan akan barang dan jasa tersebut. Dalam usaha memenuhi permintaan wisatawan diperlukan investasi di bidang transportasi dan komunikasi, perhotelan dan akomodasi lain, industri kerajinan dan industri produk konsumen, industri jasa, rumah makan restoran dan lain-lain. ${ }^{4}$

3 Republik Indonesia, 1999, UndangUndang Otonomi Daerah, Kuraiko Pratama Bandung, Undang-Undang Nomor 10 Tahun 2009 Tentang Kepariwisataan.

4 J James Spillane, Pariwisata Indonesia Siasat Ekonomi dan Rekayasa Kebudayaan. (Yogyakarta: Kanisius, 1994), hlm. 20 
Sejalan dengan hal tersebut dampak pariwisata terhadap kondisi sosial ekonomi masyarakat lokal dikelompokan oleh Cohen (1984) menjadi delapan kelompok besar, yaitu (1) dampak terhadap penerimaan devisa, (2) dampak terhadap pendapatan masyarakat, (3) dampak terhadap kesempatan kerja, (4) dampak terhadap harga-harga, (5) dampak terhadap distribusi masyarakat atau keuntungan, (6) dampak terhadap kepemilikan dan control, (7) dampak terhadap pembangunan pada umumnya dan (8) dampak terhadap pendapatan pemerintah. Majunya industri pariwisata suatu daerah sangat bergantung kepada jumlah wisatawan yang datang, karena itu harus ditunjang dengan peningkatan pemanfaatan Daerah Tujuan Wisata (DTW) sehingga industri pariwisata akan berkembang dengan baik. Negara Indonesia yang memiliki pemandangan alam yang indah sangat mendukung bagi berkembangnya sektor industri pariwisata di Indonesia. Sebagai negara kepulauan, potensi Indonesia untuk mengembangkan industri pariwisata sangatlah besar.

Industri pariwisata ini mempunyai peranan penting dalam upaya pembangunan dan pengembangan suatu daerah. Bahkan pada beberapa daerah menunjukkan bahwa industri pariwisata mampu mendongkrak daerah tersebut dari keterbelakangan dan menjadikannya sebagai sumber pendapatan utama. Pentingnya industri pariwisata dalam pembangunan dan pengembangan suatu daerah, tidak terlepas dari kenyataan bahwa:

1. Pariwisata merupakan sektor jasa yang inheren dengan kehidupan masyarakat modern. Semakin tinggi pendidikan dan ekonomi seseorang atau masyarakat, maka kebutuhan terhadap pariwisata akan semakin besar pula.

2. Pariwisata mempunyai kekuatan sinergetik karena keterkaitan yang erat sekali dengan berbagai bidang dan sektor lainnya. Pariwisata akan berkembang seiring dengan perkembangan transportasi, telekomunikasi, sumberdaya manusia, lingkungan hidup dan lain sebagainya.

3. Tumpuan pariwisata sebagai kekuatan daya saing terletak pada sumber daya yang terolah dengan baik.

Banyaknya masyarakat Cirebon yang berprofesi sebagai pedagang mempunyai harapan bahwa semua dagangan dan jasa yang mereka tawarkan kepada wisatawan dapat memuaskan dan nantinya wisatawan akan kembali lagi untuk menikmati dagangan dan jasa yang mereka tawarkan. Keberadaan wisatawan banyak memberikan masukan atau devisa bagi daerah atau masyarakat setempat karena mereka membelanjakan uang yang dibawanya untuk makan, minum, membeli cinderamata dan sebagainya. Masyarakat daerah setempat secara tidak langsung merasakan adanya dampak dari pariwisata tersebut. Dampak yang menguntungkan seperti terciptanya lapangan pekerjaan, meningkatnya pendapatan, dan meningkatnya keramaian. Sedangkan dampak yang merugikan seperti mahalnya harga barang-barang, rusaknya daerah sekitar dan melunturnya kebudayaan.

Berdasarkan latar belakang yang telah diuraikan, maka dalam penelitian ini terdapat pertanyaan antara lain sebagai berikut:

1. Bagaimana peluang usaha masyarakat sekitar obyek wisata religi di Kota Cirebon?

2. Bagaimana peningkatan pendapatan yang didapat oleh pedagang kawasan obyek wisata religi di Kota Cirebon?

3. Bagaimana penyerapan tenaga kerja di daerah kawasan obyek wisata religi di Kota Cirebon? adalah:

Adapun tujuan penelitian ini,

1. Untuk mengetahui peluang usaha masyarakat sekitar obyek wisata religi di Kota Cirebon. 
2. Untuk mengetahui peningkatan pendapatan yang didapat oleh pedagang kawasan obyek wisata religi di Kota Cirebon.

3. Untuk mengetahui penyerapan tenaga kerja di daerah kawasan obyek wisata religi di Kota Cirebon.

\section{Landasan Teori \\ Wisata Religi}

\section{Pengertian Wisata Religi}

Wisata berasal dari bahasa sansekerta VIS yang berarti tempat tinggal masuk dan duduk. Kemudian kata tersebut berkembang menjadi Vicata dalam bahasa Jawa Kawi kuno disebut dengan wisata yang berarti bepergian. Kata wisata kemudian memperoleh perkembangan pemaknaan sebagai perjalanan atau sebagian perjalanan yang dilakukan secara sukarela serta bersifat sementara untuk menikmati obyek dan daya tarik wisata. ${ }^{5}$

Wisata religi yang dimaksudkan disini lebih mengarah kepada wisata ziarah. Secara etimologi ziarah berasal dari bahasa Arab yaitu zaaru, yazuиru, Ziyarotan. Ziarah dapat berarti kunjungan, baik kepada orang yang masih hidup maupun yang sudah meninggal, namun dalam aktivitas pemahaman masyarakat, kunjungan kepada orang yang telah meninggal melalui kuburannya. Kegiatannya pun lazim disebut dengan ziarah kubur.

Dalam Islam, ziarah kubur dianggap sebagai perbuatan sunah yaitu apabila dikerjakan mendapat pahala dan apabila ditinggalkan tidak berdosa. Praktik ziarah sebenarnya telah ada sebelum Islam, namun dilebih-lebihkan sehingga Rasulullah sempat melarangnya. Tradisi ini pun dihidupkan kembali

5 Khodiyat, Ramaini. Kamus Pariwisata dan Perhotelan. (Jakarta : Gramedia Widiasarana Indonesia, 1992), hlm. 123 bahkan dianjurkan untuk mengingat kematian. $^{6}$

Praktik ziarah sebenarnya telah ada sebelum Islam, namun dilebih-lebihkan sehingga Rasulullah sempat melarangnya. Tradisi inipun dihidupkan kembali bahkan dianjurkan untuk mengingat kematian. Perkembangan pariwisata Indonesia mengalami pasang surut tidak sesuai dengan perkembangan zaman. Hal tersebut berlaku pula terhadap pariwisata religi yang berada di Indonesia. Obyek wisata potensial banyak dikunjungi baik oleh wisatawan domestik maupun mancanegara. Kecenderungan wisatawan lebih suka memilih wisata religi dibandingkan dengan obyek wisata lainnya. Sehubungan dengan hal tersebut, pemerintah sudah selayaknya mengupayakan agar obyek wisata religi lebih ditingkatkan dengan merencanakan dan melakukan strategi yang matang serta efektif agar pariwisata religi dapat berperan aktif dalam meningkatkan devisa di Indonesia.

Indonesia merupakan negara yang penduduknya menganut beberapa agama, seperti Islam, Kristen, Katolik, Protestan, Hindu, dan Budha. Contoh dari wisata religi, perayaan tahun baru Agama Budha (Waisyak) di Candi Borobudur yang mendatangkan wisatawan domestik dari seluruh Indonesia, pemeluk agama Budha dari seluruh dunia, Perayaan Hari Eka Dasa Rudra (1979) yang diselenggarakan setiap 100 tahun, dan Hari Panca Wali Krama yang diselenggarakan setiap 10 tahun, di Pura Besakih Bali berhasil menarik jutaan umat Hindu seluruh dunia. Di luar negeri Umat Kristen secara teratur melakukan perjalanan agama ke pusat agama Katolik di Vatikan Roma, Gerramergam, Lourdes dan setiap cabang gereja yang ada.

\footnotetext{
${ }^{6}$ Ruslan, Arifin S. N. Ziarah Wali Spiritual Sepanjang Masa. (Yogyakarta: Pustaka Timur. 2007), hlm. 6
} 
Umat Protestan berbondongbondong mengunjungi gereja megah seperti Notre Dame Catedral di Paris atau Saint Peter di Roma. Di antara sekian banyak tempat ziarah yang paling terkenal yang ada di dunia adalah kunjungan ke Mekkah dan Madinah untuk ibadah haji dan ke Israel untuk ziarah bagi umat Islam. Bahkan di luar negeri sejak agama berkembang beberapa ratus tahun yang lalu pariwisata religi ini telah dilakukan jutaan umat manusia secara berkelompok. Mereka melakukan perjalanan untuk memberikan penghormatan ke tempat suci tertentu sebagai penebusan dosa atau untuk memenuhi janji ketika sakit. ${ }^{7}$

Hal yang sama juga berlaku bagi umat Kristen dan Protestan di Indonesia yang pergi ke Roma dan Yerussalem untuk turut merayakan Natal, namun dapat dikatakan hampir tidak ada wisatawan mancanegara yang datang ke Indonesia. Salah satu moment besar yang berkaitan dengan perkembangan agama Islam di Indonesia dan berhasil mendatangkan wisatawan mancanegara dalam jumlah besar adalah festival Istiqlal. ${ }^{8}$

Sesungguhnya pariwisata telah dimulai sejak dimulainya peradaban manusia itu sendiri yang ditandai dengan adanya pergerakan manusia yang melakukan ziarah atau perjalanan. Namun demikian tonggak-tonggak sejarah dalam wisata sebagai fenomena modern dapat ditelusuri dari perjalanan Marcopolo (1054-1324) yang menjelajahi Eropa dan Tiongkok. Untuk kembali ke Venesia, perjalanan Pangeran Henry (1394-1460). Christopher Colombus (1451 -1506) dan Vasco da Gama sedangkan sebagai kegiatan ekonomi, pariwisata baru berkembang pada awal abad ke-19 dan

${ }^{7}$ Mc. Intoch, Hobert. Tourism Principles, Practices and Philosophies. (Ohio: Grid Inc. Iim Rogayah Dana Saputra 1997), hlm, 35-36

8 Pitana dan Diarta. Pengantar Ilmu Pariwisata. (Yogyakarta: Andi. 2009), hlm. 27 sebagai industri Internasional pariwisata tahun $1869 .{ }^{9}$

Para teolog Islam merumuskan dua macam ziarah yakni:

a. Ziarah Syariyah, yaitu ziarah yang dilakukan dengan maksud mendo'akan si mayat dan mengambil pelajaran (i'tibar) dengan keadaan mereka pada waktu masih hidup. Mereka telah mati, telah dipendam, telah menjadi tanah dan mereka telah menjumpai apa yang telah mereka perbuat baik berupa kebaikan atau keburukan.

b. Ziarah Bid'iyah (syirkiyah), yaitu ziarah yang dimaksudkan memohon kepada si mayat untuk memenuhi hajat seseorang atau meminta do'a dan syafa' at kepadanya atau berdoa di dekat kuburannya dengan keyakinan bahwa doanya lebih terkabul.

MUI perlu mengeluarkan fatwa sehubungan dengan adanya penyimpangan praktik keagamaan dalam makam yang mengarah pada perbuatan syirik. MUI perlu mengadakan re-edukasi terhadap masyarakat peziarah untuk memberikan pemahaman yang benar tentang makam dan aktivitas ritualnya, sehingga dapat mengeliminir pemahaman bahwa makam adalah keramat. MUI perlu mengadakan pelurusan pemahaman agama Islam di kalangan juru kunci makam, mubaligh, dan peziarah. ${ }^{10}$

\section{Fungsi Wisata Religi}

Wisata religi dilakukan dalam rangka mengambil ibrah atau pelajaran dan ciptaan Allah atau sejarah peradaban manusia untuk membuka hati sehingga menumbuhkan kesadaran bahwa hidup di dunia ini tidak kekal.

Wisata pada hakikatnya adalah perjalanan untuk menyaksikan tandatanda kekuasaan Allah, implementasinya dalam wisata kaitannya dengan proses

\footnotetext{
${ }^{9}$ Gasperz, Vincent. Perencanaan Strategik untuk Peningkatan Kinerja Sektor Publik. (Jakarta: Gramedia Pustaka Utama, 2004), hlm. 45 10

http://aslibumiayu.wordpress.com/2010/08/12
} 
dakwah dengan menanamkan kepercayaan akan adanya tanda-tanda kebesaran Allah sebagai bukti ditunjukkan berupa ayatayat dalam Al-Qur'an.

\section{Bentuk- bentuk Wisata Religi}

Wisata religi dimaknai sebagai kegiatan wisata ke tempat yang memiliki makna khusus, seperti:

a. Masjid sebagai tempat pusat keagamaan dimana masjid digunakan untuk beribadah sholat, i'tikaf, adzan dan iqomah.

b. Makam dalam tradisi Jawa, tempat yang mengandung kesakralan. Makam dalam bahasa Jawa merupakan penyebutan yang lebih tinggi (hormat) pesarean, sebuah kata benda yang berasal dan sare, (tidur). Dalam pandangan tradisional, makam merupakan tempat peristirahatan. ${ }^{11}$

c. Candi sebagai unsur pada jaman purba yang kemudian kedudukannya digantikan oleh makam.

\section{Tujuan Wisata Religi}

Tujuan wisata religi mempunyai makna yang dapat dijadikan pedoman untuk menyampaikan syiar Islam di seluruh dunia, dijadikan sebagai pelajaran untuk mengingat ke-Esaan Allah, mengajak dan menuntun manusia supaya tidak tersesat kepada syirik atau mengarah kepada kekufuran. ${ }^{12}$

Ada 4 faktor yang mempunyai pengaruh penting dalam pengelolaan wisata religi yaitu lingkungan eksternal, sumber daya dan kemampuan internal, serta tujuan yang akan dicapai. Suatu keadaan, kekuatan, yang saling berhubungan dimana lembaga atau organisasi mempunyai kekuatan untuk mengendalikan disebut lingkungan

11 Suryono, Agus. 2004. Paket Wisata Ziarah Umat Islam. (Semarang: Kerjasama Dinas Pariwisata Jawa Tengah dan Stiepari Semarang. 2004), hlm. 7

12 Ruslan, Arifin S. N. Ziarah Wali Spiritual Sepanjang Masa. (Yogyakarta: Pustaka Timur, 2007), hlm. 10 internal, sedangkan suatu keadaan, kondisi, peristiwa dimana organisasi atau lembaga tidak mempunyai kekuatan untuk mengendalikan disebut lingkungan eksternal. Kaitan antara wisata religi dengan aktivitas dalam adalah tujuan dari wisata ziarah itu sendiri. ${ }^{13}$

Abidin (1991: 64) menyebutkan bahwa tujuan ziarah kubur adalah: ${ }^{14}$

a. Islam mensyariatkan ziarah kubur untuk mengambil pelajaran dan mengingatkan akan kehidupan akhirat dengan syarat tidak melakukan perbuatan yang membuat Allah murka, seperti minta restu dan do'a dari orang yang meninggal.

b. Mengambil manfaat dengan mengingat kematian orang-orang yang sudah wafat dijadikannya pelajaran bagi orang yang hidup bahwa kita juga akan mengalami seperti yang mereka alami yaitu kematian.

c. Orang yang meninggal diziarahi agar memperoleh manfaat dengan ucapan do'a dan salam oleh para peziarah tersebut dan mendapatkan ampunan.

\section{Pengelolaan Wisata}

\section{Pengertian Pengelolaan}

Pengelolaan berasal dari kata kerja mengelola dan merupakan terjemahan dari bahasa Italia yaitu menegiare yang artinya menangani alat-alat, berasal dari bahasa latin manus yang artinya tangan. Dalam bahasa Prancis terdapat kata mesnagement yang kemudian menjadi management. Menurut kamus besar bahasa Indonesia pengelolaan berasal dari kata kelola yang berarti mengendalikan, mengurus dan menyelenggarakan.

Di sisi lain Efendi menyatakan manajemen berasal dari bahasa Inggris yaitu to manage yang memiliki kesamaan dengan kata to hand yang berarti "mengurus", to control "memeriksa", to

13 Rammad Dwi Jatmiko, Manajemen Stratejik. (Malang: Universitas Muhammadiyah Malang Press. 2003), hl. 30

14 Abidin, Zaenal. 1991. Alam Kubur dan Seluk Beluknya, Solo: Rineka Cipta. 
guide "memimpin atau membimbing", jadi apabila dilihat dari asal katanya manajemen berarti pengurusan, pengendalian, memimpin atau membimbing.

Manajemen adalah suatu proses yang diterapkan oleh individu atau kelompok dalam upaya-upaya koordinasi untuk mencapai suatu tujuan. Dalam skala aktivitas manajemen dapat diartikan sebagai aktivitas mengatur, menertibkan dan berpikir yang dilakukan oleh seseorang, sehingga mampu mengemukakan, menata, merapikan segala sesuatu yang ada di sekitarnya sesuai dengan prinsip-prinsip serta menjadikan hidup lebih selaras, serasi dengan yang lainnya. Upaya mengefektifkan pengelolaan dan pengembangan di lingkungan internal maupun eksternal yang ada termasuk di dalamnya kecenderungan terhadap pariwisata dalam konteks global. ${ }^{15}$

Dari dua penjelasan di atas dapat diambil kesimpulan bahwa manajemen merupakan aktivitas yang mencakup perencanaan adalah proses penentuan tujuan dan pedoman pelaksanaan dengan memilih yang terbaik dari alternatifalternatif yang ada. Pengorganisasian adalah suatu proses penentuan, pengelompokan dan pengaturan bermacam-macam aktivitas yang diperlukan untuk mencapai tujuan. Pengarahan adalah mengarahkan semua bawahan, agar mau bekerja sama dan bekerja efektif untuk mencapai tujuan serta pengendalian dan pengawasan adalah proses pengaturan berbagai faktor dalam suatu perusahaan agar sesuai

15 Agus Suryono, Paket Wisata Ziarah Umat Islam. (Semarang: Kerjasama Dinas Pariwisata Jawa Tengah dan Stiepari Semarang. 2005), hlm. 1 dengan ketetapan-ketetapan dalam rencana. ${ }^{16}$

Dalam pengelolaan wisata keagamaan atau wisata religi, terdapat beberapa hal yang harus diperhatikan:

a. Perlu pembentukan forum rembug masyarakat setempat untuk membahas pengembangan daya tarik wisata religi tematis keagamaan/ziarah muslim secara tepat dengan memperhatikan potensi kekayaan budaya lokal yang ada.

b. Perlu perlengkapan berupa pembuatan induk pengembangan (master plan) RTBL (Rencana Tata Bangunan dan Lingkungan) dan dibahas secara lintas sektoral. Beberapa hal termasuk pula persyaratan-persyaratan teknis untuk pendirian suatu bangunan (building code).

c. Perlu dikembangkan pula, "Collaborative Management" antara instansi-instansi yang berkepentingan (lintas sektor) dengan maksud untuk tetap menjaga kelestarian sejarah dan budaya yang ada.

Adapun pola-pola lintas sektor yang harus dikembangkan untuk pengelolaan daya tarik wisata religi adalah dengan semangat $4 \mathrm{M}$ :

a. Mutual Respect (saling menghormati)

b. Mutual Trust (saling percaya)

c. Mutual Responsibility

(saling bertanggungjawab)

d. Mutual Benefit (saling memperoleh manfaat) ${ }^{17}$

Arti penting pengelolaan dalam konteks manajemen adalah memungkinkan sekelompok orang untuk mencapai tujuan organisasional secara bersama-sama. Selain itu pengelolaan memungkinkan kerjasama antar orangorang dan individu di dalam organisasi untuk mencapai tujuan tertentu.

16 Hasibuan, Malayu S.P. Manajemen Sumber Daya Manusia Edisi Revisi. (Jakarta: Bumi Aksara. 2011), hlm. 41

17 Suryono, Agus. Paket Wisata Ziarah Umat Islam. (Semarang: Kerjasama Dinas Pariwisata Jawa Tengah dan Stiepari Semarang. 2004), hlm. 11 


\section{Manajemen Wisata}

Manajemen yang baik dan efektif memerlukan penguasaan atas orang-orang yang dikelola. Dalam kegiatan wisata terdiri atas beberapa komponen utama yaitu wisatawan, elemen geografi dan industri pariwisata. Pengertian dari masing-masing komponen diatas adalah sebagai berikut:

a. Wisatawan adalah aktor dalam kegiatan wisata dengan melakukan perjalanan wisata akan menjadi sebuah pengalaman manusia untuk menikmati, mengantisipasi dan mengingatkan dalam masa-masa kehidupan.

b. Pergerakan wisatawan berlangsung pada tiga area geografi yaitu daerah asal wisatawan, tempat ketika dia melakukan aktivitas keseharian, seperti bekerja, belajar, tidur dan kebutuhan dasar lain. Rutinitas ini mendorong seseorang untuk melakukan wisata dari daerah asal, seseorang dapat mencari informasi tentang obyek dan daya tarik wisata yang diminati, membuat pemesanan kemudian menuju ketempat tujuan wisata. Daerah tujuan wisata ini sering disebut dengan ujung tombak pariwisata. Di daerah tujuan wisata, dampak pariwisata sangat dirasakan sehingga sangat dibutuhkan perencanaan dan manajemen yang tepat.

c. Industri pariwisata adalah industri yang menyediakan jasa, daya tarik, dan sarana wisata.

Sebagai contoh, biro perjalanan wisata dapat ditemukan pada daerah asal wisatawan, penerbangan dapat ditemukan baik di daerah asal maupun pada tempat transit serta akomodasi dapat ditemukan pada daerah tujuan wisata.

Pariwisata merupakan kegiatan yang dapat dipahami dari banyak pendekatan. Dalam Undang-undang RI nomor 10 tahun 2009 tentang Kepariwisataan dijelaskan bahwa wisata adalah kegiatan perjalanan yang dilakukan oleh sekelompok orang dengan mengunjungi tempat tertentu untuk tujuan rekreasi, pengembangan pribadi, atau mempelajari keunikan daya tarik wisata yang dikunjungi dalam jangka waktu sementara. Adapun yang dimaksud dengan pariwisata sendiri adalah berbagai macam kegiatan wisata dan didukung berbagai fasilitas serta layanan yang disediakan oleh masyarakat, pengusaha, dan pemerintah. ${ }^{18}$

Wisata adalah kegiatan yang tidak dapat terlepas dari kehidupan manusia. Setiap orang akan membutuhkan kegiatan berwisata dan pariwisata baik yang dilakukan didalam daerah maupun diluar daerah tempat tinggalnya. Wisatawan dalam melakukan perjalanan dengan berbagai tujuan antara lain bersenangsenang, tujuan bisnis dan profesional dan tujuan lain-lain sehingga wisatawan dibedakan menjadi wisatawan vakansi dan wisatawan bisnis dengan cara tersendiri. Para wisatawan dapat melakukannya di dalam negeri atau pariwisata domestik dan perjalanan keluar negeri atau mancanegara.

Manfaat wisata menurut Kotler membagi wisatawan dari manfaat yang ingin diraihnya ketika melakukan perjalanan wisata. Wisatawan dalam melakukan perjalanan wisata tentunya ingin mendapatkan sesuatu karena perjalanan wisata harus berimbang dengan perjalanan yang dilakukannya. Manfaat perjalanan yang dicari oleh setiap orang beragam yaitu mulai dari kualitas yang merupakan kata kunci dalam industri pariwisata. ${ }^{19}$

Kualitas disini berperan sangat penting bagi para wisatawan yang mencari mutu yang tinggi dan berapapun akan dibayarnya. Pelayanan adalah serangkaian

18 Ismayanti, Pengantar Pariwisata, (Jakarta: Gramedia, 2010), hlm. 3

19 Philip Kotler, Manajemen Pemasaran. edisi kesebelas, (Jakarta: Indeks kelompok Gramedia. 2006), hlm. 273 
kegiatan yang dirancang untuk memenuhi kepuasan wisatawan, pelayanan disini adalah inti dari kegiatan wisata dan membuat produk wisata menjadi unik. Aspek ekonomis yaitu sebagian wisatawan menginginkan manfaat ekonomis dari pariwisata, mereka akan memperhitungkan untung dan rugi dari setiap keputusan berwisata. Para wisatawan juga membutuhkan ketepatan dan kecepatan dalam hal penyediaan jasa.

Keragaman perjalanan wisata dibentuk dari karakter-karakter manusia yang berbeda-beda. Wisatawan dapat dikelompokkan berdasarkan jenisnya. Para ahli mengembangkan beragam jenis wisatawan pada prinsipnya perilaku jenis wisatawan mempunyai jenis yang sama yaitu motivasi kegiatan dan perjalanan.

Adapun fasilitas yang digunakan wisatawan adalah transportasi yang meliputi angkutan darat, air dan udara. Angkutan udara digunakan oleh para wisatawan dalam jarak jauh dan waktu tempuh yang panjang, sedangkan angkutan darat digunakan untuk menjemput kedatangan wisatawan sesuai dengan rute perjalanan.

Transportasi darat dapat mencapai daerah yang sulit bahkan area yang sulit sekalipun. Transportasi air memberikan kenyamanan tersendiri bagi para wisatawan misal kapal feri, kapal pesiar, kapal danau dan perahu. Sarana akomodasi sangat dibutuhkan untuk setiap kegiatan wisata, karena kegiatannya membutuhkan waktu lebih dari 1 hari. Sehingga seluruh akomodasi umumnya menyediakan jasa pelayanan penginapan yang dilengkapi dengan makan dan minum serta jasa lain dalam wujud yang seragam.

\section{Unsur-unsur Manajemen Wisata}

Unsur adalah kesatuan yang tidak dapat dipisahkan dan berkaitan satu sama lainnya. Salusu menyebutkan manajemen memiliki unsur-unsur yang saling mendukung dan tidak dapat dipisahkan yaitu $6 \mathrm{M}$ meliputi: ${ }^{20}$

a. Man (Manusia)

Manusia merupakan unsur pendukung yang paling penting untuk pencapaian sebuah tujuan yang telah ditentukan sehingga berhasil atau gagalnya suatu manajemen tergantung pada kemampuan untuk mendorong dan menggerakkan orang-orang ke arah tujuan yang hendak dicapai.

b. Money (uang)

Segala aktivitas dalam sebuah lembaga tentu membutuhkan uang untuk operasional kegiatan.

c. Material

Dalam proses kegiatan, manusia membutuhkan bahan-bahan materi, karena materi merupakan unsur pendukung manajemen dalam rangka pencapaian tujuan.

d. Machine (mesin)

Peranan mesin sangat dibutuhkan agar proses produksi dan pekerjaan bisa berjalan efektif dan efisien.

e. Method (metode)

Untuk pelaksanaan pekerjaan perusahaan perlu membuat alternatifalternatif cara (metode) agar produk bisa berdaya guna dan berhasil guna dan sesuai dengan perkembangan yang menawarkan berbagai metode baru untuk lebih cepat dan baik dalam menghasilkan barang dan jasa.

f. Market (pemasaran)

Bagi kegiatan yang bergerak di bidang wisata, pasar sangat penting sebagai pencapaian tujuan akhir. Pasar yang menghendaki seorang manajer untuk mempunyai orientasi. Penjelasan tentang 6M kaitannya dengan fungsi manajemen Menurut Leiper pengelolaan manajemen merujuk kepada seperangkat peranan atau fungsi manajemen yaitu planning, directing, organizing dan controlling.

${ }^{20}$ Salusu, J. 1996. Pengambilan Keputusan Strategik. (Jakarta: Grasindo, 1996), hlm. 1 


\section{Metode Penelitian}

Untuk mendapatkan sebuah penelitian yang akurat, ilmiah dan sistematis, maka diperlukan seperangkat metodologi yang tepat dan memadai. Kerangka metodologis yang akan penulis gunakan cukup sederhana, namun penulis memandang kerangka ini cukup tepat, yaitu:

\section{Jenis Penelitian}

Jenis penelitian ini adalah penelitian lapangan (Field Research) dan eksploratorif yaitu berupa penjelajahan tentang dampak keberadaan wisata religi terhadap perkembangan ekonomi masyarakat Cirebon yang datanya diperoleh dengan terjun langsung ke objek penelitian.

\section{Pendekatan Penelitian}

Penelitian ini menggunakan pendekatan penelitian kualitatif di mana penulis berusaha mengekplorasi kedalaman data yang di peroleh dari wawancara dengan responden sehingga data yang diperoleh menjadi valid untuk di analisis.

\section{Lokasi penelitian}

Lokasi penelitian ini adalah tempattempat wisata religi yang ada di Cirebon baik di kota maupun kabupaten dimana tempat tersebut menjadi tujuan wisata bagi orang-orang yang berkunjung ketika berada di Cirebon.

\section{Metode Pengumpulan Data}

Data penelitian ini meliputi tiga data yaitu data primer, data sekunder, dan data tersier. Data primer adalah data yang diperoleh dari hasil wawancara. Data tersier adalah sebagai data pelengkap, data primer, dan data sekunder seperti majalah hukum, koran, dan web atau blog yang di ambil dari internet serta kamus dan ensiklopedi.

\section{Metode Analisis Data}

Setelah data diperoleh, selanjutnya akan dianalisis dengan teknik analisis deskriptif-kualitatif. Analisis deskriptif digunakan untuk mendeskripsikan pandangan responden tentang keberadaan wisata religi yang kemudian diuraikan sebagai sebuah narasi, kemudian diperhatikan sisi-sisi data yang harus atau memang memerlukan analisa lebih lanjut.

\section{ANALISIS DAN PEMBAHASAN \\ Peluang Usaha Masyarakat Sekitar Obyek Wisata Religi di Kota Cirebon}

\section{Toko Pakaian}

Masyarakat berjualan pakaian yang lokasinya di sekitar Makam Sunan Gunung Jati dan memanfaatkan rumah mereka sebagai toko. Banyak masyarakat Gunung Jati yang rumahnya berdekatan dengan Makam Sunan Gunung Jati, mereka membuka toko dirumahnya sendiri dan menjadi toko permanen.

Seperti yang dikatakan ibu Warni yang berusia 45 tahun dan warga kelurahan Gunung Jati Gang 4 mengatakan:

"Saya membuka usaha toko ini sudah lama mbak, ini usaha saya pribadi, karena rumah saya yang berdekatan dengan makam Sunan Gunung Jati jadi saya buka toko dan berjualan baju batik tulis gedog. Saya berjualan baju batik tulis gedog karena merupakan baju khas Cirebon atau produk lokal masyarakat Cirebon. Jualan disini ada paguyuban yang mengaturnya, didata dari paguyuban dan ada iuran setiap bulannya. Saya merasa senang bisa berjualan di sekitar lokasi makam Sunan Gunung Jati ini, karena Mbah Sunan Gunung Jati sudah meninggal namun beliau masih bisa memberikan kehidupan bagi orang banyak." 21

Jadi Ibu Warni adalah salah satu dari warga asli Kelurahan Kutorejo yang membuka toko pakaian dirumahnya

${ }^{21}$ Wawancara dengan ibu Warni (penjual pakaian), Toko beliau: 2 April 2016, 09.30 
sendiri karena lokasi rumahnya yang berdekatan dengan makam Sunan Gunung Jati. Toko ini sudah turun temurun dari dulu sehingga bangunan toko ini merupakan bangunan permanen.

\section{Warung makanan}

Peluang usaha yang dimiliki oleh masyarakat untuk memanfaatkan lokasi wisata religi Sunan Gunung Jati cukup banyak, salah satunya ialah dengan cara membuka warung makan. Membuka usaha warung makan dilakukan oleh Ibu Lilis warga asli Gunung Jati. Seperti yang dikatakan Ibu Lilis warga Gunung Jati Gang 4 yang berusia 35 tahun mengatakan:

"Saya membuka warung makan ini karena sudah banyak orang yang berjualan baju jadi saya membuka usaha lainnya. Warung makan ini ada disini sudah lumayan lama dari almarhumah ibu saya dulu. Ini warung makan saya sendiri, karena rumah saya ya disini di Gang 4 yang merupakan lokasi makam Sunan Gunung Jati. Ini warung warisan dan Alhammdulillah rame, Wisata religi Sunan Gunung Jati itu sudah meninggal tapi bisa memberi rizki bagi orang banyak. Karena saya dapat bekerja dan mendapat uang ya dari kerja berupa membuka usaha warung makan ini disekitar makam Sunan Gunung Jati.",22

Jadi menurut ibu Lilis banyak orang membuka usaha berupa warung makan disekitar makam Sunan Gunung Jati ialah merupakan warung warisan dari leluhurnya karena rumah beliau yang berada di lokasi makam Sunan Gunung Jati. Sehingga banyak masyarakat asli kelurahan Gunung Jati membuka warung makan di rumah mereka sendiri-sendiri. Selain membuka warung makan ada juga yang jualan makanan ringan dan jajanan yang biasanya dibuat oleh-oleh bagi para

22 Wawancara dengan ibu Lilis (penjual makanan), warung beliau: 2 April 2016, 13.30 peziarah yang berkunjung ke makam Sunan Gunung Jati.

Seperti Hendra warga Cirebon pemilik lapak yang berjualan makanan Ringan. Berikut kata beliau saat peneliti wawancarai. Saya berjualan disini sudah lama sekali, namun pada tahun 2012 ada peraturan dari Pemerintah Cirebon dilarang untuk berjualan di depan Musium Kambang putih Cirebon. Maka saya dan beberapa pedagang lainnya berusaha untuk mempertahankan lapak dagangan kami maka, dibentuklah kelompok paguyuban para pedagang kaki lima (PKL) yang berada didepan Musium Kambang Putih. Penghasilan yang saya peroleh dengan berjualan makanan ringan di sini setiap minggunya sekitar kurang lebih 5 juta rupiah. Maka dengan kondisi ini saya bisa merasakan berkah dari Sunan Gunung Jati dan saya merasa senang dengan keberadaan makam Sunan Gunung Jati di Kelurahan saya." 23

\section{Jual Aksesoris}

Lokasi sekitar makam Sunan Gunung Jati merupakan tempat yang strategis untuk membuka berbagai macam usaha. Jenis usaha yang ada disini selain toko yang dijual selain pakaian batik Cirebon dan berbagai jenis makanan ada juga yang berjualan berbagai macam aksesoris. Aksesoris yang dijual di tempat ini berbagai macam mulai gelang, kalung, dan gantungan kunci yang bergambar sunan Gunung Jati serta berbagai macam aksesoris lainnya. Seperti yang dikatakan oleh ibu Kholifah usia 35 tahun seorang pedagang aksesoris warga Kelurahan Gunung Jati RT 7.

"Saya jualan di lokasi makam Sunan Gunung Jati ini, jualan gelang-gelang mainan, kalung mainan, bros serta gantungan kunci. Saya jualan di sini sudah

23 Wawancara dengan Hendra (Penjual Makanan Ringan), di toko beliau, 20 April 2016, 15.20 
lama kurang lebih sekitar sepuluh tahun. Alhamdulillah saya dapat berjualan dilokasi ini, serta saya dapat penghasilan yang lumayan banyak dan juga dekat dari rumah." 24

Dari keterangan yang disampaikan oleh ibu Kholifah, maka bisa dilihat bahwa beliau sangat merasa senang karena rumahnya berada didekat makam Sunan Gunung Jati serta dapat berjualan disekitar makam. Dari sinilah kehidupan sebagian besar masyarakat khususnya kelurahan Gunung Jati merasakan dampak positif dari lokasi tempat tinggal mereka.

\section{Penginapan}

Berbagai jenis usaha dapat dilakukan oleh masyarakat yang berusaha memanfaatkan lokasi wisata religi makam Sunan Gunung Jati salah satunya ialah membuka penginapan umum disekitar lokasi. Seperti keterangan yang disampaikan oleh ibu Wahyuni warga kelurahan Gunung Jati RT 4 yang berusia 30 tahun mengatakan.

Jenis usaha berupa penginapan umum cukup banyak ada disekitar lokasi makam Sunan Gunung Jati ini. Yang semuanya dimiliki oleh warga Kelurahan Gunung Jati khususnya yang rumahnya berada di gang 4. Variasi jenis usaha dilakukan oleh masyarakat sekitar makam Sunan Gunung Jati agar dapat menghasilkan uang salah satunya dengan membuka penginapan dan ponten umum.

\section{Tempat Parkir Sepeda Motor}

Pemanfaatan lokasi makam Sunan Gunung Jati yang dilakukan oleh masyarakat selanjutnya ialah membuka lahan parkir sepeda motor, seperti yang dilakukan oleh Pak Arifin warga Kelurahan Gunung Jati RT 4 yang berusia 40 tahun.

Jenis usaha berupa tempat parkir sepeda motor disekitar makam Sunan

${ }^{24}$ Wawancara dengan ibu Kholifah (Penjual aksesoris), lapak beliau, 2 April 2016, 15.00
Gunung Jati ada 4 tempat yang semuanya milik warga kelurahan Gunung Jati. Dari 4 lokasi parkir yang berada di dalam gang 4 para pemilik tempat parkiran tersebut tidak menjalankan usahanya sendiri tapi membaginya dengan orang lain yang bekerja sebagai tukang parkir. Para tukang parkir ini tidak semuanya berasal dari Kelurahan Gunung Jati namun banyak yang berasal dari daerah lain seperti, dari Kecamatan Montong, Merak Urak, Rengel, Kelurahan Bonsari, sehingga dari membuka jenis usaha tempat parkir ini dapat memberi pekerjaan bagi orang lain.

\section{Peningkatan Pendapatan Pedagang Kawasan Obyek Wisata Religi di Kota Cirebon}

\section{Pemanfaatan Objek Wisata Religi}

Secara mikro, aspek ekonomi dalam kepariwisataan dapat djelaskan bahwa dengan adanya perkembangan pariwisata akan memberi dampak positif bagi pendapatan masyarakat sekitar daerah tujuan obyek wisata karena dengan meningkatnya arus wisatawan, masyarakat disekitar obyek wisata dapat memanfaatkan untuk membuka usaha yang kira-kira dibutuhkan oleh wisatawan.

Dalam usaha pembangunan daerah menjadi daerah tujuan pariwisata diperlukan daya tarik dari obyek wisata. Dalam usahanya tesebut diperlukan suatu pemasaran untuk mempromosikan dan mengenalkan potensi wisata yang dimilikinya. Pemanfaatan teknologi informasi akan sangat membantu dalam mengenalkan potensi wisata kepada masyarakat luas dan mampu menarik investor untuk berinvestasi disuatu daerah wisata tersebut.

Obyek wisata religi di Cirebon merupakan obyek wisata yang mempunyai jumlah arus kunjungan yang lebih ramai daripada obyek wisata lain di Cirebon. Obyek wisata religi tersebut adalah obyek wisata makam Sunan Gunung Jati, Masjid 
Sangsekerta, Kacirebonan, Masjid AtTaqwa, dan Gua Sunyaragi.

Pada obyek wisata religi/ziarah tersebut sangat potensial untuk dikembangkan karena kondisi masyarakat Cirebon yang agamis. Hal tersebut terbukti dengan selalu ramainya arus kunjungan pada obyek wisata makam Sunan Gunung Jati Masjid Sangsekerta, Kacirebonan, Masjid At-Taqwa, dan Gua Sunyaragi ketika terdapat acara Haul pada kedua obyek wisata tersebut. Hal itu mampu memberikan peluang kepada masyarakat untuk membuka usaha bagi wisatawan baik pada Obyek Wisata makam Sunan Gunung Jati, Masjid Sangsekerta, Kacirebonan, Masjid AtTaqwa, dan Gua Sunyaragi.

Potensi wisata adalah semua obyek (alam, budaya, buatan) yang memerlukan banyak penanganan agar dapat memberikan nilai daya tarik bagi wisatawan. Potensi wisata alam di Cirebon pada umumnya masih perlu perbaikan dan pengembangan lebih lanjut karena masih belum optimalnya pengelolaan untuk mengembangkan potensi-potensi obyek wisata di Cirebon.

\section{Dampak Sosial}

Cirebon tidak akan seperti sekarang ini jika tidak ada makam Sunan Gunung Jati, Masjid Sangsekerta, Kacirebonan, Masjid At-Taqwa, dan Gua Sunyaragi. Apalagi semakin majunya atau semakin baiknya sarana transportasi serta lancarnya sarana transportasi, peziarah semakin banyak pula. Apalagi fasilitas dan pelayanan makin baik, setelah ditangani oleh masyarakat. Dengan semakin banyaknya pengunjung atau peziarah dan wisatawan memberikan kesempatan penduduk sekitar makam untuk memenuhi kebutuhan para peziarah. Dengan pengertian lain keberadaan makam Sunan Gunung Jati sangat berpengaruh terhadap kehidupan masyarakat di sekitarnya.
Adanya Obyek wisata Religi akan membuka lapangan pekerjaan yang didapatkan oleh masyarakat, berarti akan membantu meningkatkan pendapatan bagi keluarganya. Pendapatan tersebut mampu untuk membiayai kebutuhan rumah tangganya dan untuk membiayai sekolah anak-anaknya. Hal ini seperti dituturkan oleh Ibu Umi 45 tahun mengatakan:

"...penghasilan saya memang tidak terlalu besar, tapi saya bisa memenuhi kebutuhan hidup sehari-hari dan membiayai sekolah anak-anak saya. Sebelum jualan disini saya hanya menjadi buruh pabrik yang upahnya hanya bisa untuk makan seharihari, dan biaya sekolah anak-anak ditanggung oleh suami". ${ }^{25}$

Masyarakat sangat terbantu dengan dibukanya makam Sunan Gunung Jati sebagai objek wisata religi, hal ini seperti penuturan Bapak Sutopo (48 tahun) mengatakan:

"Masyarakat memiliki lapangan pekerjaan, dulunya banyak masyarakat sini yang menganggur, tapi setelah Makam Sunan Gunung Jati dibuka menjadi obyek wisata kami menjadi memiliki pekerjaan. Ada yang berjualan, juru kunci, tukang parkir, petugas kebersihan. Berarti kan menyerap tenaga kerja dan membuka peluang kerja". ${ }^{26}$

Dari uraian di atas dapat diambil suatu kesimpulan bahwa dengan objek wisata religi mempunyai pengaruh sosial terhadap masyarakat sekitar. Pengaruh tersebut diantaranya adalah sebagai berikut:

a. Mengubah status sosial masyarakat yang tadinya pengangguran menjadi tidak pengangguran lagi (punya pekerjaan).

b. Membuka peluang usaha, yang tadinya tidak punya usaha akhirnya memiliki usaha sendiri seperti punya warung

25 Wawancara dengan Ibu Umi, 27 September 2016

${ }^{26}$ Hasil wawancara dengan Bapak Sutopo, 29 September 2016 
makan, toko souvenir, menyewakan kamar mandi, dan sebagainya.

c. Meningkatnya pendidikan bagi masyarakat. Adanya pekerjaan bagi masyarakat, berarti menambah penghasilan orang tua, dengan demikian anak-anaknya dapat melanjutkan sekolah ke jenjang yang lebih tinggi.

d. Bisa menambah pengetahuan dan wawasan yang lebih luas lagi bagi masyarakat sekitar.

\section{Dampak Ekonomi}

Dampak ekonomi dapat bersifat positif maupun negatif dalam setiap pengembangan obyek wisata. Untuk segi positif dampak ekonomi ini ada yang langsung dan ada juga yang tidak langsung. Dampak positif langsungnya adalah membuka lapangan pekerjaan yang baru untuk komunitas lokal, baik itu sebagai pegawai bagian kebersihan, kemananan, ataupun lainnya yang sesuai dengan kemampuan, skill masyarakat sekitar yang bisa dipergunakan oleh pihak pengelola wisata, atau dengan berjualan, seperti: makanan, minuman atau voucher hp di sekitar lokasi wisata sehingga masyarakat lokal bisa mendapatkan peningkatan taraf hidup yang layak. Selain untuk masyarakat lokal, dampak ekonomi juga akan berpengaruh bagi pemerintah daerah yang akan mendapatkan pendapatan dari pajak. Sedangkan dampak ekonomi yang tidak langsung adalah kemajuan pemikiran akan pengembangan suatu obyek wisata, adanya emansipasi wanita sehingga wanita pun bisa bekerja. Suatu pengembangan obyek wisata apabila diatur, ditata dan dipantau dengan baik tidak akan menghasilkan dampak negatif bagi sektor ekonominya, tetapi apabila tidak dilakukan, diatur, ditata dengan baik maka akan menimbulkan kerugian baik bagi pihak pengembang obyek itu sendiri maupun pihak komunitas lokal daerah setempat.
Bila dilakukan dengan benar dan tepat maka pariwisata dapat memaksimalkan keuntungan dan dapat meminimalkan permasalahan. Penduduk setempat mempunyai peran yang sangat penting dalam upaya pengembangan obyek wisata, karena penduduk setempat mau tidak mau terlibat langsung dalam aktifitas-aktifitas yang berkaitan dengan kepariwisataan di daerah tersebut, misalnya bertindak sebagai tuan rumah yang ramah, penyelanggara atraksi wisata dan budaya khusus (tarian adat, upacaraupacara agama, ritual, dan lain-lain), produsen cindera mata yang memiliki kekhasan dari obyek tersebut dan turut menjaga keamanan lingkungan sekitar sehingga membuat wisatawan yakin, tenang, aman selama mereka berada di obyek wisata tersebut. Akan tetapi apabila suatu obyek wisata tidak dikembangkan atau ditangani dengan baik atau tidak direncanakan dengan matang, dapat menyebabkan kerusakan baik secara lingkungan maupun dampak-dampak negatif terhadap ekonomi maupun sosial.

\section{Penyerapan Tenaga Kerja di Daerah Kawasan Obyek Wisata Religi di Kota Cirebon \\ Masyarakat Dapat Menciptakan Lapangan Pekerjaan}

Melihat begitu pentingnya pelibatan masyarakat lokal dalam usaha pengembangan pariwisata yang dilihat sebagai usaha meminimalisir kelemahan yang bersumber dari lingkungan internal yaitu banyak fasilitas obyek wisata di Cirebon yang rusak dan tidak terawat juga digunakan untuk menghindari ancaman dari lingkungan eksternal yaitu masih kurangnya peran serta masyarakat dalam sektor pariwisata.

Manusia dalam bekerja biasanya cenderung ikut orang lain atau menjadi karyawan, namun sejatinya manusia menginginkan bekerja di tempatnya sendiri dengan membuka berbagai jenis 
usaha. Sehingga manusia dapat menciptakan lapangan pekerjaan untuk dirinya sendiri. Maka kondisi ini terjadi pada masyarakat yang memanfaatkan sekitar lokasi wisata religi di Cirebon. masyarakat yang memiliki tempat tinggal di sekitar lokasi wisata tersebut dapat membuka berbagai jenis uasaha karena tempat tinggal mereka yang berada di lokasi wisata religi sehingga, menimbulkan peluang untuk membuka usaha. Seperti keterangan yang disampaikan oleh Bapak Ali pemilik toko baju lokasi Masjid Agung Sang Ciptarasa.

Saya merasa sangat senang karena lokasi tempat tinggal saya berdekatan dengan Masjid Agung Sang Ciptarasa yang berada di Gang 4 atau RT 4 kelurahan Kota Cirebon karena beliau dapat membuka usaha dengan berjualan baju. Lokasi ini dikatakan sangat strategis untuk membuka berbagai jenis usaha karena selalu ramai oleh kedatangan para peziarah. Toko di lokasi ini bisa buka 24 jam karena para peziarah yang datang sewaktu-waktu. Dari kondisi ini saya dapat membuka tempat kerja untuk keluarga bahkan orang lain. Saya memiliki karyawan yang bekerja sebagai penjaga toko saya. ${ }^{27}$

Seperti juga dikatakan seorang penjual kaki lima berada di lingkungan Keraton Kesepuhan yang suadah lama membuka usahanya mengatakan:

"Dengan adanya Keraton Kasepuhan Cirebon maka terbuka lapangan kerja bagi masyarakat setempat untuk membuka usaha kecil-kecilan, baik di area Keraton Kasepuhan Cirebon maupun di perumahan lingkungan sekitar. ${ }^{28}$

Inisiatif masyarakat dengan memanfaatkan lokasi di sekitar objek wisata religi ini, maka mereka dapat membuka usaha sendiri dan bahkan dapat memberi pekerjaan bagi orang lain. Yang

${ }^{27}$ Wawancara dengan pak Ali (pemilik toko baju), toko beliau, hari Kamis 2 April 2016, 10.00

${ }^{28}$ Wawancara dengan Ibu Ita menciptakan pekerjaan sendiri tidak hanya Pak Ali pemilik toko baju namun banyak para pemilik usaha-usaha lain yang berada disekitar makam Sunan Gunung Jati seperti Ibu Wahyuni pemilik penginapan dan ponten umum. Berikut ucapan bu Wahyuni saat diwawancarai.

"Saya merasa dapat membantu orang lain lewat penginapan dan ponten umum yang saya miliki. Saya memiliki beberapa orang yang bekerja dengan saya. Maka dengan adanya penginapan dan ponten umum ini saya tidak harus bekerja dengan orang lain, tapi saya dapat membuka lapangan pekerjaan sendiri. ${ }^{29}$

Keadaan ekonomi masyarakat mengalami peningkatan dengan cara membuka berbagai jenis usaha sehingga dapat menciptakan lapangan pekerjaan sendiri. Masyarakat membuka berbagai jenis usaha ialah sebagai upaya untuk memperoleh pendapatan yang berguna untuk memenuhi kebutuhan dasar dan kebutuhan lainnya sehingga terwujudlah kesejahteraan ekonomi.

Jadi, pada intinya masyarakat merasakan manfaat makam Sunan Gunung Jati yang berada di Kelurahan gunung Jati memiliki dampak positif bagi perekonomian mereka. Sehingga Masyarakat dapat menciptakan lapangan pekerjaan sendiri bahkan memberi pekerjaan orang lain.

\section{Implementasi Kesejahteraan ekonomi}

Kehidupan seorang individu tidak lepas dari masalah ekonomi. Seorang individu bisa melangsungkan hidupnya jika memiliki uang untuk bertahan hidup. Agar memiliki pemasukan keuangan maka seorang individu harus bekerja. Masyarakat melakukan kegiatan ekonomi atau bekerja dengan cara membuka berbagai jenis usaha yang dapat dilakukan, seperti masyarakat yang memanfaatkan sekitar lokasi wisata religi

29 Wawancara dengan Ibu Wahyuni, (Rumah Beliau), hari Kamis 11 April 2016, 10.30 
di Cirebon. Masyarakat membuka berbagai jenis uasaha yang dikelola sendiri maka muncullah sebuah kesejahteraan ekonomi.

\section{Penutup}

\section{Kesimpulan}

berdasarkan hasil yang diperoleh dari sumber-sumber di lapangan dapat disimpulkan bahwa:

1. Adanya obyek wisata religi memiliki pengaruh yang sangat besar dalam pengembangan usaha untuk meningkatkan ekonomi masyarakat Kota Cirebon dan dapat membuka toko-toko souvenir khas Cirebon, sehingga pendapatan dapat meningkat sehingga dapat mencukupi kebutuhan keluarga bahkan dapat menabung dan meningkatkan pergaulan antar suku dan bangsa saling berkenalan, meningkatkan taraf hidup masyarakat agar dapat hidup mandiri, membina diri dan kepribadian sebagai bagian dari kekuatan dan ketahanan nasional serta meningkatkan kemakmuran dan kesejahteraan rakyat melalui pembudayaan potensi yang dimilikinya.

2. Adanya obyek wisata religi membawa dampak pada peningkatan pendapatan masyarakat Cirebon khususnya yang berada disekitar lokasi wisata, dan peningkatan pengahasilan ini akan terasa cukup signifikan apabila ada momentmoment seperti mauludan dan lain-lain.

3. Adanya wisata religi memberikan dampak yang cukup signifikan bagi kehidupan masyarakat Cirebon karena dapat terciptanya lapangan pekerjaan baru untuk warga disekitar tempat wisata baik untuk keluarga maupun untuk orang lain.

\section{Daftar Pustaka}

A. Hari Karyono, Kepariwisataan. Jakarta: Grasindo, 2007
Abidin, Zaenal. Alam Kubur dan Seluk Beluknya, Solo: Rineka Cipta. 1991

Agus Suryono, Paket Wisata Ziarah Umat Islam. SemaraNg: Kerjasama Dinas Pariwisata Jawa Tengah dan Stiepari Semarang. 2005

Andi S. Mappi, Cakrawala Pariwisata. Jakarta: Balai Pustaka, 2001

Gamal Suwantoro, Dasar-dasar Pariwisata. Yogyakarta: Penerbit Andi, 2001

Happy Marpaung, Pengetahuan Kepariwisataan, Bandung: Penerbit Alfabeta, 2002

Hasibuan, Malayu S.P. Manajemen Sumber Daya Manusia Edisi Revisi. Jakarta: Bumi Aksara. 2011

Hasil Wawancara dengan bapak ridwan selaku staf DISBUDMENPORA Kota Cirebon, 26 Juli 2016, jam 10.2011.45

Heru erwantoro, Busana Adat Pengantin Keraton Cirebon Simbol, Makna Dan Fungsisuatu Pendekatan Sejarah Kebudayaan termuat dalam situs Http://cippad.usc.edu/ai/uploaded_file s/History/Type0/File1/busana\%20ada t\%20pengantin.pdf. 25 Agustus 2007

$\underline{\text { http://aslibumiayu.wordpress.com/2010/0 }}$ $\underline{8 / 12}$

Ismayanti, Pengantar Pariwisata, Jakarta: Gramedia, 2010

J James Spillane, Pariwisata Indonesia Siasat Ekonomi dan Rekayasa Kebudayaan. Yogyakarta: Kanisius, 1994 
Khodiyat, Ramaini. Kamus Pariwisata dan Perhotelan. Jakarta: Gramedia Widiasarana Indonesia, 1992

Kusmayadi dan Sugiarto Endar, Metodologi Penelitian Dalam Bidang Kepariwisataan, Jakarta:Penerbit Gramedia Pustaka Utama, 2000

Kusuma, E. Nurmas Argadiningrat, Baluarti Kraton Kesepuhan Cirebon Cirebon: Yayasan Kebudayaan Keraton Kasepuhan Cirebon, 1998

Lundberg, E Donald., Stavenga, Mink dan M. Krishnamoorthy, Ekonomi Pariwisata. Jakarta: PT Gramedia Pustaka Utama, 2009

Mc. Intoch, Hobert. Tourism Principles, Practices and Philosophies. Ohio: Grid Inc. Iim Rogayah Dana Saputra 1997

Oka A.Yoeti, Perencanaan Strategi Pemasaran Daerah Tujuan Wisata, Jakarta: PT. Pradnya Paramita, 2005

Philip Kotler, Manajemen Pemasaran. edisi kesebelas, Jakarta: Indeks kelompok Gramedia. 2006

Rammad Dwi Jatmiko, Manajemen Stratejik. Malang: Universitas Muhammadiyah Malang Press. 2003

Ratna Suranti, Pariwisata Budaya dan Peran Serta Masyarakat, termuat dalam situs http://www.kompas.com, 26 Oktober 2008

Republik Indonesia, 1999, UndangUndang Otonomi Daerah, Kuraiko Pratama Bandung, Undang-Undang Nomor 10 Tahun 2009 Tentang Kepariwisataan.

Ruslan, Arifin S. N. Ziarah Wali Spiritual Sepanjang Masa. Yogyakarta: Pustaka Timur. 2007
Salusu, J. 1996. Pengambilan Keputusan Strategik. Jakarta: Grasindo, 1996

Sulandraningrat, P.S., Babad Tanah Sunda Babad Cirebon Cirebon: 1948

Sumadi Suryabrata, Metodologi penelitian, Jakarta: PT Raga Grafindo Persada, 1983

Suryono, Agus. Paket Wisata Ziarah Umat Islam. Semarang: Kerjasama Dinas Pariwisata Jawa Tengah dan Stiepari Semarang. 2004 